\title{
DEKONSTRUKSI TERHADAP KUASA PATRIARKI \\ ATAS ALAM, LINGKUNGAN HIDUP, DAN PEREMPUAN DALAM NOVEL-NOVEL KARYA AYU UTAMI
}

\author{
Wiyatmi, Maman Suryaman, dan Esti Swatikasari \\ FBS Universitas Negeri Yogyakarta \\ email: wiyatmi@uny.ac.id
}

\begin{abstract}
Abstrak
Penelitian ini bertujuan mendeskripsikan strategi dekonstruksi terhadap kuasa patriarki atas alam, lingkungan hidup, dan perempuan dalam novel-novel Ayu Utami. Penelitian ini menggunakan aliran pemikiran ekofeminisme. Sumber data adalah tiga novel karya Ayu Utami, yaitu Bilangan Fu, Manjali dan Cakrabirawa, dan Maya. Hasil penelitian sebagai berikut. Pertama, ketiga novel tersebut menggambarkan perjuangan tokoh dalam melawan kuasa patriarki atas alam, lingkungan, dan perempuan yang terjadi di kawasan taman bumi Sewugunung dan situs candi Calwanarang di era Orde Baru. Kedua, bentuk perlawanan yang dilakukan tokoh sejalan dengan pemikiran ekofeminisme dan merupakan strategi dekonstruksi terhadap kuasa patriarki atas alam, lingkungan, dan perempuan.
\end{abstract}

Kata kunci: ekofeminisme, alam, patriarki, novel, Ayu Utami

\section{THE DECONSTRUCTION OF PATRIARCHAL POWER OVER NATURE, ENVIRONMENT, AND WOMEN IN AYU UTAMI'S NOVELS}

\begin{abstract}
This study aims to describe deconstruction strategies against patriarchal power over nature, environment, and women in Ayu Utami's novels. The study used ecofeminism. The data sources were Ayu Utami's three novels, namely Bilangan Fu, Manjali dan Cakrabirawa, and Maya. The findings are as follows. First, the three novels portray characters' struggle against patriarchy power over nature, environment, and women in the Sewugunung park area and the Calwanarang temple site in the New Order era. Second, the forms of the resistance that the characters make are in line with ecofeminism and are deconstruction strategies against patriarchal power over nature,environment, and women.
\end{abstract}

Keywords: ecofeminism, nature, patriarchy, novels, Ayu Utami

\section{PENDAHULUAN}

Setelah sukses dengan novel pertamanya yang berjudul Saman pada tahun 1998, Ayu Utami makin mengukuhkan eksistensinya sebagai salah satu sastrawan perempuan dengan menerbitkan sejumlah novel berikutnya yaitu Larung (2001), Bilangan Fu, (2008), Manjali dan Cakrabirawa (2010), Lalita (2012), dan Maya (2013), Cerita Cinta Enrico (2012), Pengakuan Eks
Parasit Lajang (2003), dan Simple Mirache (2014). Beberapa novel tersebut merupakan novel serial yang diikat dengan tokoh dan peristiwa yang sama. Saman (1998), Larung (2001), dan Maya (2013) berada dalam satu serial dengan tema perjuangan melawan kekerasan politik era Orde Baru, selain perlawanan terhadap ketidakadilan gender. Tokoh-tokoh utamanya adalah Saman, Larung, Yasmin, Cok, Shakun- 
tala. Novel Maya menghubungkan serial Saman dengan serial Bilangan Fu karena mempertemukan tokoh dari kedua serial tersebut, yaitu Yasmin dan Saman (serial Saman) dengan Parang Jati dan Suhubudi (serial Bilangan Fu). Cerita Cinta Enrico, Pengakuan Eks Parasit Lajang, dan Simple Mirache berada dalam satu serial, berkisah tentang perjalanan tokoh dari seorang lajang sampai akhirnya mengambil keputusan menikah secara agama dan bukan pernikahan secara negara, setelah mengalami pergulatan pemikiran tentang kesetaraan gender dalam perkawinan dan keluarga dalam hubungannya dengan agama. Tokoh utama serial novel tersebut adalah A (Aku) dan Enrico.

Secara garis besar novel-novel dalam serial Bilangan $\mathrm{Fu}$ bercerita tentang upaya tokoh-tokoh dalam mendekonstruksi kuasa patriarki atas alam, lingkungan, dan perempuan di Sewugunung dan situs candi Calwanarang. Tokoh-tokoh tersebut adalah Parang Jati, Manjali, Suhubudi, dan Mbok Manyar yang menentang praktik panjat tebing kotor, eksploitasi sumber daya alam di Sewugunung dan penjarahan situs Calwanarang. Dengan berpijak pada pandangan ekofeminisme tokoh-tokoh tersebut memiliki keyakinan bahwa bumi, alam (tebing) adalah simbol femininitas, sehingga merusak dan mengeksploitasi bumi dan alam sama dengan memperkosa perempuan, memperkosa ibunda (Utami, 2008:72, 79). Selain itu, menurutnya, kekerasan terhadap manusia dan alam di Indonesia telah melampaui batas, sehingga harus dihentikan (Utami, 2008:461).

Berdasarkan latar belakang tersebut, penelitian ini akan memahami bagaimana ekofeminisme dalam novel-novel karya Ayu Utami digunakan sebagai strategi dekonstruksi terhadap kuasa patriarki atas alam, lingkungan hidup, dam perempuan dalam konteks Orde Baru yang menjadi latar cerita novel-novel tersebut. Dari kajian ini diharapkan dapat dijelaskan adanya hubungan tak terpisahkan antara kajian sastra, khususnya novel Indonesia, dengan perspektif feminis dan ekologis. Ekofeminisme diperkenalkan oleh Francoise d'Eaubonne melalui buku yang berjudul Le Feminisme ou la Mort (Feminisme atau Kematian) yang terbit pertama kali 1974 (Tong, 2006:366). Dalam bukunya tersebut dikemukakan adanya hubungan antara penindasan terhadap alam dengan penindasan terhadap perempuan (Gaard, 1993:13). Ekofeminisme berusaha untuk menunjukkan hubungan antara semua bentuk penindasan manusia, khususnya perempuan, dan alam. Dalam hal ini ekofeminisme memandang bahwa perempuan secara kultural dikaitkan dengan alam. Ada hubungan konseptual, simbolik, dan linguistik antara feminisme dengan isu ekologis (Tong, 2006:350).

\section{METODE}

Untuk mencapai tujuan penelitian design penelitian deskriptif kualitatif. Seperti dikemukakan oleh Denzin \& Lincoln (1994:2) bahwa penelitian deskriptif kualitatif interpretif mempelajari bendabenda di dalam konteks alamiahnya dan berupaya untuk memahaminya atau menafsirkan maknanya yang dilekatkan pada manusia (peneliti) kepadanya. Sumber data adalah novel Bilangan Fu, Manjali dan Cakrabirawa, dan Maya karya Ayu Utami yang terindiksi menggambarkan adanya kuasa patriarki atas alam, lingkungan hidup, dan perempuan. Di samping itu, juga dikumpulkan data yang berhubungan dengan informasi adanya kuasa patriarki atas alam, lingkungan hidup, dan perempuan dalam konteks analisis ekofeminisme. Selanjutnya, data tersebut dicatat dalam kartu data dan diklasifikasikan sesuai dengan informasi. Analisis data dilakukan dengan analisis wacana kualitatif interpretif dengan pendekatan ekofeminisme melalui kegiatan kategorisasi, tabulasi, dan inferensi. Kategorisasi digunakan untuk mengelompokkan data berdasarkan kategori yang telah ditetap- 
kan, yaitu adanya kesadaran ekofeminisme yang terdapat dalam pilihan kata, kalimat, wacana yang digunakan dalam teks novel yang diteliti. Tabulasi digunakan untuk merangkum keseluruhan data dalam bentuk tabel. Inferensi digunakan untuk menginterpretasikan dan menyimpulkan hasil penelitian sesuai dengan permasalahan penelitian. Dalam penelitian ini inferensi didasarkan pada kerangka teori ekofeminisme.

\section{HASIL PENELITIAN DAN PEMBA- HASAN}

Dengan memfokuskan pada masalah bagaimana aliran pemikiran ekofeminisme sebagai strategi dekonstruksi terhadap kuasa patriarki atas alam, lingkungan, dan perempuan dalam serial novel Bilangan $\mathrm{Fu}$, maka penelitian berhasil menemukan dua hal, yaitu (1) ketiga novel tersebut menggambarkan perjuangan beberapa tokoh dalam melawan kuasa patriarki atas alam, lingkungan, dan perempuan yang terjadi di kawasan taman bumi Sewugunung dan hutan kawasan candi Calwanarang di era Orde Baru, (2) bentuk perlawanan yang dilakukan oleh sejumlah tokoh dalam ketiga novel sejalan dengan pemikiran ekofeminisme dan merupakan strategi dekonstruksi terhadap kuasa patriarki atas alam, lingkungan, dan perempuan.

\section{Perlawanan terhadap Kuasa Patriarki Atas Alam, Lingkungan, dan Perempuan}

Ketiga novel serial Bilangan Fu menggambarkan adanya perlawanan terhadap kuasa patriarki atas alam, lingkungan, dan perempuan yang terjadi di kawasan taman bumi Sewugunung dan hutan kawasan candi Calwanarang di era Orde Baru. Perlawanan tersebut dilakukan oleh Parang Jati, Suhubudi, Marja manjali, Mbok Manyar. Kuasa patriarki yang dilawan oleh tokoh-tokoh tersebut adalah praktik panjat tebing yang merusak alam, penambangan kapur, batu, penebangan pohon secara besar-besaran, pemaksaan menanam padi jenis tertentu, pengebiran terhadap komunitas tertentu, dan marginalisasi perempuan mantan anggota Gerwani.

Perlawanan tersebut diawali dengan pertemuan Parang Jati dengan Sandi Yuda, seorang pemanjat tebing yang telah berhasil menjalankan ekspedisi di sejumlah tebing di Jawa Barat dan merambah ke Sewugunung. Praktik panjat tebing yang selama ini dilakukan oleh Sandi Yuda dan kawan-kawannya, ternyata menyalahi aturan panjat tebing yang seharusnya. Dengan menggunakan alat bantu panjat berupa bor, paku, dan pasak untuk memaku dan mengebor tebing yang akan dipanjat, ternyata mereka sudah melakukan kekerasan yang menyebabkan kerusakan dan kehancuran tebing. Parang Jati menganggap praktik panjat seperti itu sebagai panjat kotor, karena melukai dan memperkosa alam. Dalam hal ini Parang Jati menganggap alam sebagai simbol femininitas, sehingga memanjat tebing sambil melukainya, sama dengan memperkosa perempuan.

Aku merasa ia memainkan kekalahanku. Pertama, dengan menyebut "watununung-mu" Kami memang selalu menganggap tebing yang kami panjat sebagai milik kami. Sindirannya menegaskan belaka bahwa tak ada yang benar milik kami. Kedua, dan ini yang lebih menyakitkan karena memang jitu- dengan menunjukkan bahwa gunung batu itu lebih menyerupai lambang farji dari pada falus. Buat kami ketika itu memanjat adalah membuktikan diri sebagai lelaki sejati. Tebing bagi kami adalah tonggak. Dan tonggak adalah lingga. Tapi brengsek kini ia menunjukkan bahwa tebing kami adalah garba...

Dengan mata bening sialannya ia berkata: apa yang sedang kau ingin taklukkan, yang kau anggap sebagai musuh, tak lain tak bukan adalah femininitas. Ya. Tebing batu yang kau paku dan bor itu...(Utami, 2008:37). 
Menurut Parang Jati, apabila seorang pemanjat tebing tidak dapat menjalankan panjat bersih, lebih baik tidak memanjat tebing, seperti tampak pada kutipan berikut.

Perkaranya lebih besar daripada kasus yang tampak. Yaitu bahwa manusia begitu tamak. Dan bagian dari kerakusan lelaki adalah ingin menaklukkan alam, dengan cara memperkosanya. Persis seperti tindakan mereka terhadap perempuan. Mereka memaku, mengebor, memasang segala jerat demi melampaui tebing. Atau mereka membeli. Dan jika mereka mencapai puncak itu dengan segala kerusakan yang dibuat, betapa dungunya. Mereka kira mereka telah berjaya (Utami, 2008:79).

Dari dua buah kutipan tersebut tampak bahwa aktivitas para pemanjat tebing dilakukan oleh para laki-laki untuk membuktikan kejantanannya sebagai laki-laki sejati, dengan menaklukkan tebing sebagai simbol femininitas. Menaklukkan tebing dengan alat yang melukai tebing, oleh Parang Jati dianggap sama dengan memperkosa alam, simbol perempuan.

Lokasi Sewugunung yang menjadi latar cerita dalam serial novel Bilangan Fu merupakan lokasi fiksional yang mengacu pada Gunung Sewu Geopark yang ada di dekat pantai selatan perbatasan Daerah Istimewa Yogyakarta (DIY), terutama Gunung Kidul dengan Jawa Timur (Pacitan) (www.gunungsewugeopark.org). Selama bertahun-tahun, lokasi ini telah menjadi area penambangan karst oleh warga setempat maupun para pengusaha. Hal ini menimbulkan keprihatinan para aktivis lingkungan. Bahkan Direktur Eksekutif Wahli (Wahana Lingkungan Hidup) DIY, Suparlan menyatakan bahwa penambangan karst jelas merupakan tindakan yang menghancurkan kawasan lindung geologis secara sistemik. Karst sebagai potensi wisata Gunung Kidul tidak mungkin di- perbaiki apabila mengalami kerusakan. Oleh karena itu, pihaknya telah mengeluarkan surat pernyataan dukungan kepada Pemkab Gunung Kidil bernomor 178/B-II/WY/ED/VII/2011 yang dikirim kepada bupati tentang upaya pengelolaan dan penyelamatan karst dari eksploitasi para penambang (www.antaranews.com/ berita/266060/). Kerusakan ekosistem karst Gunungsewu juga telah mendorong para aktivis lingkungan, instansi terkait, dan akademisi untuk mengatasi mengatasi masalah tersebut. Pada 27 November 2007 Kementerian Negara Lingkungan Hidup memfasilitasi lokakarya penyusunan Renstra Konservasi dan Pengendalian Kerusakan Kawasan Karst Gunungsewu, yang melibatkan instansi pusat, pemerintah daerah, akademisi, LSM, dan kelompok masyarakat dari tiga kabupaten terkait yang diselenggarakan di Wisma Magister Managemen Universitas Gadjah Mada (www.menlh.go.id/). Dalam novel Bilangan Fu peristiwa ini digambarkan pada kegiatan yang diikuti Parang Jati sebagai salah satu orang yang terlibat aktif dalam upaya konservasi dan pengendalian kerusakan kawasan karst Sewugunung (Gunung Sewu) (Utami, 2008:451).

Dalam Bilangan Fu digambarkan Parang Jati menentang keras praktik panjat kotor yang dilakukan Sandi Yuda dan kawan-kawannya dan memperkenalkan konsep panjat bersih, yaitu panjat tebing tanpa alat yang melukai dan memperkosa tebing, bahkan mengajak tebing berdialog.

Tapi pemanjatan bersih yang dimaksud si mata bidadari itu agaknya lebih mirip dengan pemanjatan suci. Di dalamnya orang tidak boleh melukai tebing. Peralatan yang dapat digunakan hanyalah yang tidak bersikap sewenang-wenang pada alam. Tinggalkanlah bor, piton, paku, maupun pasak. Bawalah di sabuk kekangmu pengaman perangko, penahan, sisip, dan pegas. Juga tali-tali ambin. Maka, pasanglah pengaman sesuai dengan 
sifat batu yang kau temui, tanpa merusaknya sama sekali. Jika kau tak bisa menempuhnya, maka kau itu tak bisa memanjat. Begitu saja. Itu tak mengurangi kehormatanmu sama sekali. Tak mengurangi kejantananmu juga. Sacred climbing. (Utami, 2008:72)

"Tapi pemanjat sejati harus berdialog dengan tebingnya. Sebab, yang ia ingin taklukkan tak lain adalah tebing itu sendiri. Pemanjat sejati baru berhasil memanjat jika ia tidak merusak tebingnya. Jika ia merusak tebing, apa bedanya dengan begundal?

"Perampok atau serdadu itu memperkosa. Tapi seorang satria atau gentleman sejati bersetubuh dengan perempuan dalam hubungan dialogis."(Utami, 2008:81).

Konsep panjat bersih yang dianut Parang Jati mendekonstruksi praktik panjat tebing yang selama ini dilakukan oleh Sandi Yuda dan kawan-kawannya, termasuk para militer. Parang Jati mendekonstruksi pandangan Sandi Yuda bahwa, yang mungkin juga sesuai dengan pandangan umum, tebing yang mereka panjat adalah tonggak, simbol lingga, falus. Dalam pandangan Parang Jati, tebing adalah simbol garba, rahim ibu pertiwi. Konsep panjat bersih yang dikenalkan Parang Jati kepada Sandi Yuda sebenarnya telah dikenal dalam etika panjat tebing. Panjat tebing adalah suatu olah raga yang mengutamakan kelenturan dan kekuatan tubuh dan kecerdikan serta keterampilan penggunaan peralatan dalam menyiasati tebing. Panjat tebing menaiki atau memanjat tebing yang memanfaatkan celah atau tonjolan yang digunakan sebagai pijakan atau pegangan dalam suatu pemanjatan untuk menambah ketinggian (www.skygers.cp.id). Kalau pun harus menggunakan alat bantu, pelaku panjat tebing tidak diperolehkan merusak tebing. Para pemanjat harus mengikuti sejumlah etika panjat tebing, seperti yang dirumuskan oleh Pengda Federasi Panjat Tebing
Indonesia (FPTI) DIY, yaitu (1) menghormati adat istiadat masyarakat masyarakat setempat, (2) tidak mencemari sumber air penduduk setempat, (3) tidak melakukan tindakan yang menyebabkan erosi, (4) tidak mengganggu tanaman dan satwa penduduk, (5) membatasi sedikit mungkin penggunaan kapur magnesium, (6) membatasi pemakaian bor, dan harus dipertanggungjawabkan, (7) tidak diperbolehkan menambah pengaman pada jalur yang sudah ada, dengan tujuan untuk mengurangi tingkat kesulitan, (8) diperbolehkan mengabaikan pengaman yang ada pada jalur pemanjatan dengan tujuan untuk meningkatkan tingkat kesulitan, (9) tidak melepas pengaman yang tadi dibuat dan harus diberi tanda yang jelas, (10) jika jalur baru akan diselesaikan oleh orang lain harus seijin pembat jalur pertama, (11) apabila ada pemanjatan pada satu jalur, maka sebaiknya tidak ada pemanjatan lain pada jalur tersebut (www.fpti-sleman.blogspot.co.id). Etika panjat tebing tersebut pada dasarnya sesuai dengan konsep panjat bersih yang disampaikan Parang Jati kepada Sandi Yuda dan kawan-kawannya.

Selain menyadarkan para pemanjat tebing agar mereka tidak memanjat dengan melukai dan memperkosa alam, Parang Jati juga harus berhadapan dengan para mengusaha dan kekuasaan yang melakukan penebangan pohon-pohon jati di hutan-hutan yang dilindungi dan penambangan batu kapur secara berlebihlebihan di Sewunungung. Dalam hal ini Parang Jati mendekonstruksi logika patriarki yang menganggap alam dan seisinya bukan sebagai makhluk hidup, tetapi sebagai sumber kapital dan fundamen investasi (Candraningrum, 2013:4-5), sehingga bisa dieksplorasi dan eksploitasi sebesar-besarnya. Misi penyelamatan alam dan lingkungan hidup dijalankan Parang Jati karena tugas dari ayah angkatnya, Suhubudi, yang menganggap alam sebagai rahim bagi kehidupan manusia.

Dekonstruksi terhadap Kuasa Patriarki atas Alam, Lingkungan Hidup, dan Perempuan ... 
Engkau diselamatkan di hutan, di tebing pegunungan batu yang menerbitkan tiga belas mata air bagi desa ini. Maka kelak engkau harus menyelamatkan mereka: hutan, pegunungan gamping yang melahirkan tiga belas mata air. Mereka rahim keduamu. Mereka menjagamu. Maka, jagalah mereka... (Utami, 2008:290)

Parang Jati semula adalah bayi yang ditemukan di mata air oleh Mbok Manyar, penjaga mata air di desa Sewugunung, dan selanjutnya diserahkan kepada Suhubudi. Suhubudi adalah seorang guru kebatinan dan tokoh supranatural di Sewugunung yang mempunyai relasi dengan sejumlah tokoh nasional di Indonesia, bahkan menjadi penasihat spiritual sejumlah pejabat negara (Utami, 2014).

Kerusakan ekosistem di Sewugunung tampak dari kutipan berikut.

Mbok Manyar mengajak kami menyadari betapa air telah keruh dan surut. Ada nada marah dalam suaranya, meski ia tidak mengeluhkan siapapun. Parang Jati menjelaskan kepadaku bahwa belakangan ini beberapa sendang desa tak lagi jernih. Bahkan kolamnya lekas mengering sebelum puncak kemarau. Itu terjadi semenjak hutan-hutan jati di bukit terlarang ditebangi dan batu-batu kapur ditambangi....(Utami, 2008:151).

Nyi Manyar melihat ke depan: penggerusan bebatuan di bukit ini semakin rakus dan perkasa. Tak hanya orang-orang desa yang menambang kecil-kecilan untuk kebutuhan sendiri, dengan tobong-tobong kurus bersahaja. Orang-orang desa yang selalu mengadakan sesajen raya sebelum penambangan kecil. kini dinamit mulai meledak di sana sini. Traktor penggaruk mulai bekerja di kaki bukitbukit. Truk-truk pengangkut batu mulai keluar masuk jalan-jalan desa (Utami, 2008:225).
Dari kutipan tersebut tampak bahwa kerusakan ekosistem di Sewugunung terjadi akibat kuasa patriarki yang mendapat dukungan dari penguasa. Mbok Manyar, sang penjaga air (sendang) di Sewugunung merupakan ibu yang menjaga sumber hidup dan menyelamatkan bayi Parang Jati yang dibuang orang tuanya. Dari kutipan di atas juga tampak pandangan Suhubudi yang menyatakan bahwa alam adalah rahim kedua yang menjaga manusia, sebuah pandangan yang akhirnya mendasari pandangan Parang Jati dan mencoba merealisasikannya dalam perbuatannya. Oleh karena itu, ketika hutan-hutan jati dan bukit kapur di Sewugunung dieksploitasi besar-besaran oleh para penambang liar dan perusahaanperusahaan besar dan dilindungi oleh kepala desa Parang Jati menjadi orang pertama yang berani mengajak kepala desa untuk menghentikan proyek yang dilindunginya.

Parang Jati menggunakan kesempatan itu untuk sedikit menyinggung tentang sendang-sendang desa yang telah mulai keruh. Sebagian sumber air itu telah berwarna coklat tanah sekarang, karena hutan-hutan di perbukitan di atasnya telah rusak. "Apa tidak bisa penebangan liar itu dihentikan?" ia tak tahan tak menambahkan. "Penambangan skala besar itu juga merusak ekosistem kawasan ini," dan mengundang Pak Pontiman untuk hadir dalam diskusi lanjutan yang akan diadakan para peneliti besok lagi. Agar Pak Pontiman tahu betapa dunia luar menghargai kawasan ini semantara kepala desa itu tidak. Pak Pontiman menjawab dengan gayanya yang khas..., kata pertama yang keluar dari mulutnya adalah: setuju. Ia setuju pada segala yang dikatakan Parang Jati. Tetapi.... tidak sesederhana itu, Nak Jati... Keadaan krisis moneter ini membuat masyarakat terkondisi untuk melanggar hukum..., (Utami, 2008:292) 
Tentu saja kepala desa menolak permintaan Parang Jati, karena dirinya merupakan bagian dari proyek tersebut.

Pontiman Sutalip nama kepala desa itu. Kaisar Yulius kecil. ia seorang prajurit angkatan darat yang nyaris seumur hidupnya menjadi kepala desa di Sewugunung. Itu sesungguhnya sebuah data yang sejak awal pantas kucurigai.... Belakangan aku mendengar bahwa ia mungkin sekali berada di belakang penebangan jati yang legal maupun ilegal di Sewugunung. Posisinya adalah untuk mengamankan jalur bisnis dan distribusi laba ke "tangan-tangan yang benar." (Utami, 2008:171).

....karena kepala desa ini melancarkan izin perusahaan besar penambang batu itu bekerja di Sewugunung. Dan karena ia diam-diam mengelola penebangan jati yang kini semakin tak mengendalikan nafsu serakah. Pak Pontiman adalah agen di tubuh wilayah ini yang akan pertama-tama merusak ekosistem. (Utami, 2008; 391).

Dari kutipan tersebut tampak bahwa kepala desa Sewugunung dan para pemilik perusahaan merupakan simbol kuasa patriarki yang menjadi agen perusak ekosistem.

Itulah yang ditentang oleh Parang Jati. Untuk menjalankan misinya, Parang Jati akhirnya bekerja sama dengan sejumlah peneliti geologi dan budaya dari perguruan tinggi, khususnya dari ITB dan UGM dan lembaga lingkungan hidup, hingga akhirnya Kementerian Lingkungan Hidup melarang penambangan di bukit Sewugunung.

Dalam tahun ini Parang Jati dan tim peneliti Goa $\mathrm{Hu}$ telah berhasil menarik perhatian orang pada persoalan Sewugunung. Mereka telah berhasil melibatkan beberapa lembaga lingkungan hidup, dunia intelektual yang lebih luas, dan para aktivis hak-hak ulayat untuk menekan laju penggalian. Telah turun surat dari kementerian Lingkungan Hidup yang menghentikan penambangan karena tidak memiliki syarat analisa dampak lingkungan. Aku harus mengakui bahwa Parang Jati sangat gigih. Sama seperti ia telah mempertobatan kami dari pemanjat kotor menjadi pemanjat bersih, kini aku melihat bahwa usulusul dalam Strategi Kebudayaan-nya mulai menjadi platform tuntutan... (Utami, 2008:451).

Dari kutipan tersebut tampak bahwa melalui tokoh-tokohnya, Parang Jati, Suhubudi, Mbok Manyar, para peneliti geologi, dan pecinta lingkungan Bilangan $F u$ ditulis untuk mendekonstruksi kuasa patriarki, yang menyosok pada para pemanjat tebing yang melanggar etika panjat tebing dan orang-orang yang secara pribadi maupun kelompok, bahkan melembaga melakukan eksploitasi terhadap alam dan lingkungan tanpa mempertimbangkan kelestarian ekosistem.

Kepala desa Sewugunung, Pontiman Sutalip, tidak hanya menjadi agen patriarki yang menyebabkan kerusakan alam dan lingkungan hidup di desanya, tetapi juga melakukan kekerasan karena melarang warganya menanam padi varietas pribumi dan memaksanya mengganti dengan padi IR yang dianggap sebagai kualitas unggul. Parang Jati menjadi saksi bagaimana ayahnya, Suhubudi dan salah seorang pegawai kepercayaannya, Bandowo tetap mempertahankan menanam padi pribumi di sawahnya. Untuk menunjukkan kuasanya atas perlawanan tersebut, sang kepala desa pun menghukum Bandowo dengan memotong telapak tangannya.

Frater tahu, ayah saya menanam "padi purba" -kadang orang menyebutnya padi Majapahit- di padepokan. 
Ia mau memelihara padi nenek moyang. Ia tidak mau ikut-ikutan beralih kepada padi bikinan laboratorium. Seperti bayi tabung, kata ayah, ada jiwa yang hilang. Ayah bilang kepada kami, ia mau terus menanam padi purba di sawahnya. Paklik Bandowo mwnyahut. Ia juga akan melakukannya di sawahnya, ayah berkata, "kamu tidak perlu. Sawahmu kecil dan berada di sebelah sawah-sawah yang di bawah pengawasan Bimas, koperasi, dan lain-lain aparat desa. Apalagi ada tentara...

Suatu hari ia pulang ke rumah dan mendapati kemenakannya tidak ada, diambil tentara. Istri dan anakanaknya menangis, karena si kemenakan dianggap membangkang pemerintah. Dianggap makar, menentang pembangunan. Bandowo pun mendatangi tempat penahanan di marjas Koramil, bermaksud membebaskan anak itu. Apa yang terjadi setelah itu, sungguh sakit saya menceritakannya....

Tapi paklik Bandowo dibawa ke suatu tempat...dan di situ tangannya dipotong. Tetapak tangan kanannya hingga ke pergelangan dipotong. Saya masih menangis seriap kali menceritakan ini....(Utami, 2014:132).

Untuk menunjukkan kekuasaannya, kepala desa juga mengebiri para laki-laki kerdil dan cacat yang dikenal dengan Klan Saduki yang dirawat dan dilindungi di pedepokan Suhubudi. Mereka dianggap sebagai monster-monster yang sakit dan menyimpang, sehingga tidak boleh berkembangbiak (Utami, 2014:114-115).

Seluruh lelaki dalam Klan Saduki menjalani vasektomi -suatu operasi yang membuat mani mereka tidak berbenih lagi. Perempuannya tidak diapaapakan. Sebab Pontiman Sutalip berpikir bahwa perempuan-perempuan seperti itu tidak akan membangkitkan hasrat kecuali lelaki dari Klan saduki sendiri. Jadi, jika kaum lelakinya sudah mati benih, laum perempuannya tidak akan hamil.

Suhubudi menyaksikan peristiwa itu dengan kesedihan yang ia simpan di tempat rahasia. Bukan lantaran mereka tak bisa lagi berketurunan. Tetapi karena mereka sungguh seperti bangsa siluman yang dikalahkan.... (Utami, 2014:115).

Dari kutipan tersebut tampak bahwa sikap Suhubudi untuk mempertahankan menanam padi pribumi jelas mempertahankan salah satu tanaman yang menjadi sumber makanan pokok dan kekayaan alam Indonesia. Menggantinya dengan padi import sama saja dengan mendukung punahnya sumber makanan pribumi, yang merarti juga akan membunuh manunsia pribumi. Tindakan kapala desa dan aparat yang memotong tangan kanan Bendowo merupakan salah satu bentuk pembunuhan tersebut. Demikian juga dengan mengebiri para lelaki Klan Saduki dapat dipahami sebagai tindakan yang akan memunahkan generasi berikutnya. Padahal orang-orang kerdil dan catat yang dirawat dan dilindungi Suhubudi di padepokannya, sebagian besar berasal dari bayi-bayi cacat yang dibuang oleh orang tua mereka, bukan orang-orang yang dilahirkan dari orang cacat fisik. Mereka dilahirkan oleh orang tua yang berfisik normal, tetapi catat secara kemanusiaan.

Pada era Orde Baru, pasca gerakan 30 September 1965, semua yang berkaitan dengan Partai Komunis Indonesia harus dimusnahkan. Dalam Manjali dan Cakrabirawa, dikisahkan ketika Parang Jati dan Marja Manjali menemani seorang arkeolog Perancis (Jaques) melakukan penelitian di kawasan Candi Calwanarang di daerah Kediri, Jawa Timur secara tidak sengaja bertemu dengan Ibu Murni (alias Satinem) yang tinggal di tengah hutan dekat Candi 
Calwanarang. Murni adalah mantan anggota Gerwani, sementara suaminya, Sarwengi adalah anggota pasukan Cakrabirawa yang dibunuh oleh aparat Orde Baru atas tuduhan terlibat Gerakan 30 September 1965. Gerakan 30 September 1965 menyebabkan Murni dipenjara di Plantungan selama sepuluh tahun. Setelah keluar dari penjara, dia tinggal di tengah hutan sambil mencari informasi tempat suaminya dimakamkan.

Atas bantuan Parang Jati, Marja, dan Suhubudi, Murni akhirnya dapat menemukan makam suaminya. Pada era kekuasaan Orde Baru, Murni dan suaminya, dianggap sebagai musuh yang harus dibinasakan pemerintah (Utami, 2014:150). Mereka adalah orang-orang yang disingkirkan oleh kuasa patriarki yang menyosok pada kekuasaan militer Orde Baru. Menolong Murni yang mengasingasingkan diri di hutan dan membantu menemukan makan suaminya merupakan wujud dari dekonstruksi terhadap kuasa patriarki atas alam dan perempuan yang terpinggrikan. Mereka tidak takut dicurigai sebagai bagian dari pendukung PKI dan Cakrabirawa, seperti ketakutan yang dimiliki penduduk sekitar hutan dan situs Candi Calwanarang apabila dikaitkan dengan PKI dan Cakrabirawa.

\section{Ekofeminisme sebagai Strategi Dekons- truksi terhadap Kuasa Patriarki atas Alam, Lingkungan, dan Perempuan}

Sebagai salah satu tipe aliran pemikiran dan gerakan feminisme, maka ekofeminisme seperti halnya feminisme pada dasarnya lahir untuk melakukan dekonstruksi terhadap pemikiran dan gerakan sebelumnya yang bersifat patriarkis. Dekonstruksi pada dasarnya merupakan aktivitas pembacaan yang membaca teks dengan cara yang sama sekali baru (Sarup, 2003:86). Dekonstruksi berusaha menunjukkan bahwa pemahaman dunia kita mungkin berbeda dari pandangan yang bersandar para teori-teori yang ada sebelumnya (Sarup, 2003:92). Dekons- truksi juga dipandang sebagai salah satu metode analisis yang dikembangkan Derrida dengan membongkar struktur dari kode-kode bahasa, khususnya struktur oposisi pasangan sedemikian rupa sehingga menciptakan satu permainan tanda yang tanpa akhir dan tanpa makna akhir (Piliang, 2012:4). Sesuai dengan konsep dekonstruksi tersebut, maka penelitian ini akan memahami bagaimana kuasa patriarki atas alam, lingkungan hidup, dan perempuan dalam novel Bilangan $\mathrm{Fu}$ didekonstruksi melalui pandangan tokohtokoh yang mengusung isu ekofeminisme. Sementara patriaki itu sendiri adalah sebuah sistem yang menyebabkan laki-laki mengendalikan masyarakat melalui posisi mereka sebagai kepala keluarga (Walby, 2014:27). Walby membagi stuktur patriarki ke dalam dua jenis, patriarki privat yang beroperasi dalam ranah keluarga dan patriarki publik yang beroperasi dalam ranah publik. Dalam konteks patriarki publik, maka negara dipandang sebagai patriarki sekaligus kapitalis dan rasialis (Walby, 2014;29).

Perlawanan terhadap kuasa patriarki atas alam, lingkungan, dan perempuan yang dilakukan oleh sejumlah tokoh dalam novel seria Bilangan FuI pada dasarnya sesuai dengan perspektif ekofeminisme. Dengan perspektif ekofeminsme, Karen J Warren menyatakan jika laki-laki menganggap dirinya tuan dari alam dan telah dibeti kekuasaan atas alam, maka lakilaki akan memegang kendali atas alam, juga atas perempuan (Tong, 2006:360). Warren melihat ada keterkaitan penting antara penindasan terhadap perempuan dengan penindasan terhadap alam, sehingga pemahaman terhadap alam alam keterkaitan ini penting untuk mendapatkan pemahaman yang memadai atas penindasan terhadap perempuan dan penindasan terhadap alam. Selain itu, menurutnya pemecahan masalah ekologis harus menyertakan perspektif feminis (Tong, 2006:360). 
Konsep panjat bersih yang diperkenalkan Parang Jati untuk melawan praktik panjat kotor yang dilakukan Sandi Yuda dan kawan-kawannya sesuai dengan penjelasan Karen J. Warren, ketika mengkontraskan pemanjat tebing yang memanjat untuk mengalahkan gunung dengan pemanjat yang memahami gunung dengan cara baru. Menurut Warren, ketika seorang ekofeminis memanjat gunung, ia berasumsi bahwa ia mempunyai hubungan yang sesungguhnya dengan gunung itu. Yang menjadi perhatian seorang ekofeminis dengan mendaki hingga ke puncak bukanlah menunjukkan siapa bos antara dirinya dengan alam, tetapi lebih merupakan usaha untuk menjalin persahabatan (Tong, 2006:388). Dari persamaan pandangan tersebut, maka dapat disimpulkan bahwa konsep panjat bersih yang dikemukakan oleh Parang Jati ternyata merujuk pada pandangan Warren tersebut. Artinya, sebagai penulis Bilangan Fu, diduga Ayu Utami pun telah memahami pandangan Warren tentang panjat tebing dalam perspektif ekofeminisme.

Pandangan Parang Jati dan Suhubudi yang menyamakan alam dengan perempuan jelas merupakan pandangan ekofeminisme. Perlawanan yang dilakukan Parang Jati dan Suhubudi terhadap eksploitasi alam Sewugunung yang dilindungi oleh kapala desa dilandasi oleh perspektif ekofeminisme. Ekofeminisme memandang bahwa eksploitasi alam adalah wujud dari kapitalisme bumi dan merupakan produk patriarki yang memandang alam dan seisinya sebagai sumber kapital dan investasi (Candraningrum, 2013:5).

Perlawanan yang diakukan Suhubudi yang diikuti oleh Bandono yang menolak menanam padi import jenis IR (International Rice) di sawahnya dalam pandangan ekofeminisme sama dengan yang dilakukan oleh gerakan chipco, yaitu memeluk dan mempertahankan tumbuhan pribumi (indigenous) yang akan digantikan oleh tumbuhan import (Tong, 2006:394). Program swasembada pangan yang mengharuskan petani hanya menanam padi jenis IR dan melarang petani menanam padi lainnya, termasuk padi pribumi yang diwariskan nenek moyang sebelumnya dalam perspektif ekofeminisme dapat dipahami sebagai wujud kuasa patriarki yang melakukan penindasan terhadap alam dan perempuan. Selain itu, program swasembada pangan yang dijalankan oleh pemerintah Orde Baru dan dikenal dengan revolusi hijau telah berdampak pada marginalisasi perempuan karena penanaman bibit unggul yang tumbuh lebih rendah menyebabkan panen harus dilakukan dengan sistem tebang menggunakan sabit. Hal ini telah menghilangkan kesempatan kaum perempuan untuk ikut berperan dalam kegiatan panen menggunakan ani-ani yang merupakan pekerjaan perempuan. Pertanian pun kemudian dikuasai laki-laki karena merekalah yang menyabit padi (Fakih, 2004:14).

Berdasarkan sejumlah temuan yang telah diuraikan di atas, tampak bahwa ketiga novel karya Ayu Utami yang dikaji sengaja ditulis dengan menggunakan wawasan estetika ekofeminisme. Estetika tersebut digunakan strategi untuk mendekonstruksi kuasa patriarki atas alam, lingkungan hidup, dan perempuan khususnya di era pemerintahan Orde Baru yang dilakukan oleh individu atau pun kelompok, tetapi juga dilakukan oleh negara dengan memanfaatkan aparatnya. Selama ini oleh sejumlah pembaca dan peneliti novel-novel karya Ayu Utami dikategorikan sebagai karya yang mengusung ideologi feminisme dan menolak dominasi patriarki, seperti tampak pada penelitian Wiyatmi (2013) dan Banita (2015). Kesadaran feminisme yang telah menjiwai karya-karya Ayu Utami sebelumnya, berkembang menjadi ekofeminisme ketika karya yang ditulisnya mengangkat isu ekologis, seperti Bilangan Fu, Manjali dan Cakrabirawa, dan 
Maya. Melalui novel-novel tersebut Ayu Utami mengritisi kuasa patriarki yang menyebabkan kerusakan alam, lingkungan hidup, dan marginalisasi perempuan yang terjadi di Indonesia di era Orde Baru.

\section{SIMPULAN}

Berdasakan hasil dan pembahasan dapat disimpulkan dua hal sebagai berikut. Pertama, ketiga novel tersebut menggambarkan perjuangan beberapa tokoh dalam melawan kuasa patriarki atas alam, lingkungan, dan perempuan yang terjadi di kawasan taman bumi Sewugunung dan situs candi Calwanarang di era Orde Baru. Kedua, bentuk perlawanan yang dilakukan oleh sejumlah tokoh dalam ketiga novel sejalan dengan pemikiran ekofeminisme dan merupakan strategi dekonstruksi terhadap kuasa patriarki atas alam, lingkungan, dan perempuan. Ekofeminisme dalam ketiga novel tersebut disuarakan oleh tokoh-tokoh yang memiliki keyakinan bahwa bumi, alam (tebing) adalah simbol femininitas, sehingga merusak dan mengeksploitasinya sama dengan memperkosa perempuan, memperkosa ibunda. Melalui ketiga karyanya tersebut tampak bahwa Ayu Utami mengajak pembacanya untuk selain mengritisi kuasa patriarki juga memberikan perhatian dan penghargaan terhadap kelestarian alam dan lingkungan, serta harmonisasi, dan kesetaran gender.

\section{UCAPAN TERIMA KASIH}

Terima kasih kepada Ditjend Ristekdikti, LPPM Universitas Negeri Yogyakarta, dan para reviuwer yang telah mendanai, menfasilitasi, dan memberikan saran dan masukan untuk penyempurnaan proposal dan laporan penelitian ini.

\section{DAFTAR PUSTAKA}

Banita, Baban. 2015. "Novel Saman dan Larung Karya Ayu Utami dalam Perspektif Feminis Radikal." Laporan Pene- litian. Prodi Sastra Indonesia, Fakultas Sastra, Universitas Padjajaran Bandung.

Candraningrum, Dewi. 2013. Ekofeminisme dalam tafsir Agama, Pendidikan, Ekonomi, dan Budaya. Yogyakarta: Jalasutra.

Denzin. Norman K. \& Lincoln, Yvonna S. 2011. Qualitative Research. Edisi Ketiga. Diterkemahkan dalam Bahasa Indonesia oleh Dariyanto. Yogyakarta: Pustaka Pelajar.

Fakih, Mansour. 2004. Analisis Gender dan Transformasi Sosial. Cetakan 8. Yogyakarta: Pustaka Pelajar.

http://www.skygers,co.id/about/profil. php. Diakses melalui google.com. 5 Juli 2016.

http://www.detik.com/new s/ wawancara/969733/ayu-utami-sayatak-pernah-nulis-buku-untuk-laris). Diakses melalui google,com. 5 Juli 2016.

http://www.ayuutami.info, diakses melalui google.com 15 Juli 2016.

Gaard, Greta and Patrick D. Murphy. 1998. Ecofeminism Literary Criticsm, Theory, Interpretation, Pedagogy. USA: Board of Trustees of the Universuty if Illionis.

Piliang, Yasraf Amir. 2012. Hipersemiotika: Tafsir Cultural Studies atas Matinya Makna. Yogyakarta: Jalasutra.

Sarup, Madan. 2003. Poastrukturalisme dan Postmodernisme, Sebuah Pengantar Kritis. Yogyakarta: Jendela.

Tong, Rosemary Putnam. 2006. Feminist Thought: A More Comprehensive Introduction. Diterjemahkan dalam Bahasa Indonesia oleh Aquaini Priyatna Prabasmara. Bandung: Jalasutra.

Walby, Sylvia. 2014. Patriarchy at Work. UK, Cambridge: Polity Press.

Wiyatmi. 2013. Menjadi Perempuan Terdidik, Novel Indonesia, dan Feminisme. Yogyakarta: UNY Press. 